\title{
CoVid-19 Pandemic: An Update Clinical Features, Diagnostic Methods, Drugs and Vaccine Race
}

\author{
Théophile Uwiringiyeyezu ${ }^{1,2}$, Bouchra El Khalfi ${ }^{1}$, Rachid Saile ${ }^{3}$, \\ Jamal Belhachmi ${ }^{2}$ and Abdelaziz Soukri ${ }^{1^{*}}$ \\ ${ }^{1}$ Laboratory of Physiopathology, Molecular Genetics and Biotechnology, \\ Research Center of Biotechnology and Health, Faculty of Sciences Aïn Chock, \\ Hassan II University of Casablanca, Morocco. \\ ${ }^{2}$ Laboratory Al Kindy of Medicals Analysis, Casablanca, Morocco. \\ ${ }^{3}$ Laboratory of Biology and Health, Research Center of Biotechnology and Health, \\ Faculty of Sciences Ben M'sik, Hassan II University of Casablanca, Morocco.
}

Authors' contributions

This work was carried out in collaboration among all authors in an equal work in realizing the review, designing the study, managing the analyses and the literature searches, draft writing and correction. They also wrote, read and approved the final manuscript.

Article Information

DOI: $10.9734 / A R R B / 2020 / v 35 i 930282$

Editor(s):

(1) Dr. Bechan Sharma, University of Allahabad, India. (2) Dr. Gonzalo Emiliano Aranda Abreu, Veracruzana University, Mexico.
Reviewers:

(1) George Chege Gitao, University of Nairobi, Kenya. (2) Charunee Kasornpikul, Silpakorn University, Thailand. Complete Peer review History: http://www.sdiarticle4.com/review-history/59098

Review Article

Received 01 July 2020

Accepted 18 July 2020

Published 17 September 2020

\section{ABSTRACT}

CoViD-19 pandemic is a viral disease caused by SARS-COV-2virus and since December 2019, has spread rapidly in all the world countries; At the end of June 2020, over 10 million peoples were infected in the world and more than 500,000 deaths have been identified. Due to its fast transmission, the unavailability of drugs and vaccines and the asymptomatic patients who still spread the virus various measures were implemented to stop this virus. The studies were carried out to identify the molecular characteristics, transmission methods, origins, and all other clinical parameters necessary to eradicate it. The results have shown that CoViD-19 can be transmitted either animal-to-person or person-to-person by airborne. On March 11, 2020, world health organization (WHO) declared the CoViD-19 a pandemic, there, every concerned country has made the different health measures to stop the virus spread; the confirmed CoViD-19 patient undergoes

*Corresponding author: E-mail: ab.soukri@gmail.com, tuwiringiyeyezu@yahoo.fr; 
the validation medicals diagnostics tests to follow specific treatments as time goes staying in quarantine room of the hospital to keep away from contact with others. To treat this pandemic, the world of medicine has tried with previous treatments of other viruses with encouraging results but of course, with doubts about the success of the therapeutic effectiveness and the scientific researches continue until the development of the therapeutic medicine and the Covid-19 specific vaccine. Today, the use of anti-inflammatory drugs was reported like chloroquine/hydroxychloroquine, the antiviral drugs like ritonavir, Lopinavir, ribavirin, and remdesivir and also the glycocorticoids hormones like dexaméthasone to the patients with severe CoViD-19. Different strains of this coronavirus infect humans, bats, and other mammals. Two strains of VOC-SARS have caused outbreaks of severe respiratory disease in humans: VOC-SARS, which caused an outbreak of severe acute respiratory syndrome (SARS) between 2002 and 2003, and VOC-SARS-2, which since late 2019 has caused a coronavirus disease pandemic 2019 (COVID-19). Even if today, there are not validated CoViD-19 drugs or vaccines. In This paper, we will talk about what we know until today on SARS-COV-2 and CoViD-19 pandemic particularly the clinical symptoms, transmissions ways, biological samples concerned by SARS-COV-2 infection, medicals laboratories parameters in CoViD-19 cases, medication and medicine and molecular diagnostics methods.

Keywords: Severe acute respiratory syndrome coronavirus 2; Diagnostic methods; CoViD-19; Polymerase chain reaction; Reverse-transcription loop-mediated isothermal amplification; molecular diagnosis; biological samples; diagnostic methods; medicals analysis; clinical features.

\section{INTRODUCTION}

At the beginning of December 2020, a study reported cases of pneumonia epidemic with unknown cause [1] In China, especially in Wuhan (Hubei province),].After the investigations WHO (World Health organization) named this diseaseCOVID-19, while the viral pathogen agent was named 2019-nCov but officially named severe acute respiratory syndrome coronavirus 2 (SARS-COV-2) by the international committee on taxonomy of viruses $[2,3]$. The genome of SARS-COV-2 is a single-stranded, non-segmented positive-sense RNA, it is arranged in the order of a 5'-untranslated region (UTR)-replicase complex (Orf 1ab)-structural proteins (spike(S)-Envelope (E)-Membrane (M)Nucleocapsid (N))-3'-UTR and non-structural open-reading frames (ORFs) $[1,4]$. This genome organization is similar to that of other COVs [5]. It has a cap at its $5^{\prime}$ end and a polyadenylated end at its $3^{\prime}$ end; there are 265 nucleotides in 5'UTR and 342 nucleotides in the 3'UTR. The cap and polyadenylated tail allow the RNA genome to be directly translated by the host cell ribosome. It reaches the host cell by binding to the angiotensin-converting enzyme receptor ACE2.SARS-COV-2 was one of many viral species identified by the World Health Organization (WHO) in 2016 as one of the likely causes of a future epidemic in a new plan developed after the EBOLA epidemic for urgent research and development of screening tests, vaccines, and drugs, the prediction came true with the coronavirus pandemic 20192020.

SARS-COV-2 is identified in December 2019 in Wuhan, Hubei province of China, as a cluster of pneumonia; it was sequenced and isolated by January 2020. Today, no therapeutic or vaccines are approved against any human-infecting coronaviruses. Coronavirus spike (S) glycoprotein promotes entry into host cells relating angiotensin-converting enzyme II (ACE2) and is the main target of neutralizing antibodies. The laboratory confirmation of similarity between SARS-COV of 2002 and novel coronavirus showed that both occurred during the winter with initial cases related to an exposure to live animals sold at animal markets, The COVID-19 pandemic has resulted in many confirmed cases worldwide and over many deaths according to the world health organization (WHO).

The similarity of SARS-COV-2 with severe acute respiratory syndrome coronavirus SARS-COV was reported after Phylogenetical analysis of fulllength genome sequences from infected patients showed, it uses the same cell entry receptor, angiotensin-converting enzyme (ACE2) as SARS-COV. The possible person-to-person disease rapidly spread too many countries, without a therapeutic vaccine or specific antiviral drugs, early detection and isolation become essential against the novel coronavirus. in the beginning, this pandemic was like viral pneumonia of an unknown etiology, the 
advanced research were necessaries to find out the causative pathogen agent, the epidemiological and etiologic investigations, were conducted, after taking samples and isolate the virus, the results confirmed that the virus is SARS-COV-2 from Huanan seafood wholesale market. From the phylogenetic tree based on whole genomes, the SARS-COV-2 is parallel to the SARS-Like bat COV lineage, indicating that SARS-COV-2 is closer to the SARS-Like bat COV than SARS-COV based on the whole genome sequence [6], It was reported that 27 of the first 41 infected patients had been exposed to the Huanan seafood market [1], the discovery that pangolin coronaviruses have $85.5 \%$ to $92.4 \%$ sequence similarity to SARS-COV suggests pangolins should be considered as possible hosts in the emergence of SARS-COV-2 [7]. Today, the world report many infections cases of COVID-19, on another note, all the clinicals symptoms are known and used to refer the positive cases, with investigation on the COVID-19 patients, the epidemiological results indicate how and when the concerned patient has been contaminated, there, the different ways of transmissions are listed, diagnostic laboratories play an important role to validate the positivity or negativity of COVIOD-19 with a standard method RT-PCR and immunological tests like ELISA to appreciate the immunity and give the ways to the research about the medicine and vaccine, today the results on vaccine research continue and there is hope about the success of the vaccine assays.

\section{CLINICAL SYMPTOMS AND TRANSMISSION WAYS OF COVID-19 DISEASE}

The clinical symptoms of coronaviruses are numerous including fever, myalgia, fatigue, dry cough, dyspnoea, headache, hypoxemia, severe respiratory disease, and pneumonia. The studies reported asymptomatic infected individuals [8]. Recently, different countries are still recording clusters of COVID-19 cases with contaminated people who do not develop any clinical symptoms, this worries the sanitary measure's efforts and the emergency status that countries have established to control this virus COVID-19, in this case, mass-screen seems a most effective solution to avoid surprises. The study reported the person-to-person transmission. The SARSCOV-2 is a human-to-human pathogen that is spread by droplets produced by coughing and sneezing, however, other routes of transmission such as fecal contamination cannot be ruled out.
According to Zhong's latest experience, 4 out of the 64 stool specimens tested positive to the this virus suggesting oral-fecal route might have played a role in its rapid transmission [9], however, no cases of transmission via the fecaloral route have yet been reported, at present, respiratory transmission and direct contact transmission is the main route for SARS-COV-2. Cell receptors of angiotensin-converting enzyme II (ACE) are also expressed in absorptive enterocytes in the ileum and colon [10], this can explain the SARS-COVS-2 positive results of fecal samples, but, the fecal transmission route of the virus may be evaluated because the faecal viral viability is uncertain.

\section{THE SARS-COV-2 AND OTHER CORONA VIRUS}

The SARS-COV-2 is the seventh coronavirus to be transmitted from human-to-human like Middle East respiratory syndrome coronavirus (MERSrCOV) and SARS-associated coronavirus (SARSr-COV) [1,11,12], these three coronaviruses have crossed the species limits to cause pneumonia in humans since the beginning of the 21st century $[13,14]$ The amino acids sequences identity between the SARS-COV-2 and SARS-COV S-protein is $76.47 \%$ the current knowledge of the physical and chemical properties of coronavirus is mainly derived from the study of the SARS-COV and the MERSCOV, the viral homology with the Bat coronavirus isolate RaTG13 strain was $96 \%$ and the recent studies have shown that the homology with a coronavirus strain isolated from pangolin was $99 \%$, suggesting that SARS-COV-2 might have originated from bat and pangolin have served as the intermediate host between bat and human, however, the further research is needed to confirm these[1,15]. When the researchers compared the SARS-COV-2 with the SARS-COV at the amino-acids level, they found this virus was quite similar to the SARS-COV, but there were some notable differences in the $8 a-8 b$ and 3b protein [16], When compared with MERSCOV they found that it was distant from and less related to the MERS-COVs. Certainly, SARSCOV-2 is not a direct descendant of SARS-COV and these two strains, which are the offspring of a single ancestor, have passed to humans separately, Like SARS-COV, its viral envelope consists of a lipid bilayer where the membrane $(\mathrm{M})$, envelope (E) and spike (S) proteins are linked [17], The interaction of the spike protein with the cell receptor is central to determine the tissue tropism, infectivity and species range of 
the virus [18], it is, therefore, an important key to adaptation to the human species, within the envelope is the nucleocapsid which is formed from multiple copies of the $\mathrm{N}$ protein, linked to the RNA genome in a continuous "bead-on-achain" conformation. The lipid bilayer envelope, the membrane proteins, and the nucleocapsid protect the virus when it is outside the host. It is important to notice that these proteins are sensitive to detergents, soaps, and alcohol.

\section{REPORTED BIOLOGICAL SAMPLES IN STUDIES TO DIAGNOSE THE COVID- 19}

The research reported that nasal pharyngeal swab (NPS), sputum and stool are the recommended samples to detect SARS-COV-2 RNA signals by the molecular diagnostic methods like (Reverse-transcriptase polymerase chain reaction) RT-PCR or reverse transcription Loop-mediated isothermal amplification (RTLAMP).it is especially supported by recent data on viral loads in upper respiratory specimens with high viral loads detected in the nasal area than in the throat [19] however, whether the virus can be detected in specimens from other sites, and therefore potentially transmitted in other ways than by respiratory droplets, is unknown, there, the studies continue. This virus can be detected in bronchoalveolar lavage fluid specimens; sputum, nasal swabs, fibro bronchoscope brush biopsy, pharyngeal swabs, feces, and blood [20], SARS-COV-2 virus loads were reported to be higher in lower respiratory tract specimens [21,22]. From a diagnostic point of view, it is noted in some studies that nasal and throat swabs seem less suitable for diagnosis, since these materials contain considerably less viral RNA quantity than throat washes, and, there, the virus may escape detection if only these materials are used to test. The throat wash samples were found to be the most suitable specimens for the detection of SARS-COV.

Saliva is an oral fluid that is produced by the salivary glands represents also the main source of the human-to-human transmission of the SARS-COV-2 infection when social distance and sanitary measures of hygiene are not respected [23], the use of salivary droplets as the diagnostic sample has several advantages because saliva can be easily provided by the patient, it doesn't require specialized personnel for its collection, it is non-invasive, a patient can perform himself [24], In addition, the comfort of the procedure is significantly higher if compared with the nasopharyngeal swabs or sputum procedure and there, the procedure requires close contact between health care workers and the patients which pose risks of transmission of the virus to nurses and physicians [25], Salivary droplets can be the main tool to make reliable procedures for a mass screening like the sports events or airborne passengers, there, we can take the example of EasyCov colorimetric simple saliva test developed by Sys2Diag (France), where just with saliva sample a patient can know if he is positive or negative to CoViD-19 in an hour and the mass screening will help to get back in normal daily life and never again confine people without screening them and all asymptomatic patients cases they'll be able to find out their status on the infectivity of CoViD-19 $[26,27]$.Importantly; the live virus was detected in feces, implying that virus may be transmitted by the fecal route [20] This explains the rapid spread of disease by respiratory and extra respiratory routes. To reduce the false-negative results, the viral loads in throat swabs and sputum samples peaked at around 5-6 days after symptom onset; this is why it is recommended to test the specimens from multiples sites. The bibliography reported none urine specimens tested positive to SARS-COV-2 [20].

\section{MEDICALS LABORATORY PARA- METERS IN COVID-19 PATIENT'S CASES}

CoViD-19 patients' management requires controlling many factors like epidemiological and clinical characteristics, laboratory parameters, and radiological features. These factors help to know the imported and local cases of contaminations, identification of the most common symptoms, disease progression and complications, and serial changes of lung lesions. From mild to critical cases, the laboratory features show elevated level compared to the physiological normal values and these levels are different between CoViD-19 patients from mild-moderate to severe disease severity. Those factors are like creatine kinase $(\mathrm{CK})$, lactate dehydrogenase (LDH), aspartate transaminase (AST), alanine transaminase (ALT), total bilirubin, urea, creatinine, C-reactive protein (CRP), and procalcitonin [28]. The findings of hemograms parameters show the decrease of white blood cells lymphopenia and platelet counts [28]. Death comes as a result of progressive respiratory failure due to alveolar damage. This virus reaches the host cells by binding the Angiotensin-converting Enzyme 2 
(ACE2) receptor which is predominantly expressed by epithelial cells of the blood vessels, intestine, lung, kidney, and heart. This can explain the viral adaptation of in human species and the clinical symptoms of the CoViD-19 patients like diarrhea and intestinal inflammation in the intestine [29], hypertension, insufficiency, and cardiac arrest, cardiac enlargement, cardiac fibrosis, acute pulmonary lesion, fever, myalgia, fatigue, dry cough, dyspnoea, headache, hypoxemia, severe respiratory disease, and pneumonia.

The Renin-Angiotensin System (RAS) is known to be a central regulator of renal and cardiovascular functions and the human immune response to SARS-CoV-2 by acting on monocytes and macrophages that are essential for proper immune homeostasis [29]. Therefore, Over-activation of the RAS leads to renal and cardiovascular disorders and a cytokine storm. [30]. The dysregulation of these cells contributes to the various Covid-19 pathologies and highlights the chaotic nature of the immune response to this coronavirus. In this sense, the excessive monocytes/macrophages activation is likely responsible for the cytokine storm [30] in Covid-19 patients. Studies show that vitamin D may reduce the severity of viral infections and mortality in ventilated patients. Because, Vitamin $D$ plays a central role in the immunity of the host [31], and adequate circulating 25-hydroxy-vitamin $D$ levels are required for the proper functioning of the immune system. There, the immune cells (Band T-cells, antigen-presenting cells) express the vitamin $D$ receptor and its ligand modulates both the innate and adaptative immune responses in the host. So, its deficiency is reportedly associated with autoimmunity increased sensitivity to infection by microbial and viral pathogens, this deficiency widely occurs the elderly people, nursing home residents, obese, diabetic, hypertensive persons, and others. The disruption of vitamin $D$ signalling in animals causes RAS activation and development of hypertension. Studies in humans have shown that lower circulating 25-hydroxy-vitamin $D$ is associated with increased activity of the RAS and increased blood pressure. Vitamin $D$ is a negative regulator of RAS [32,33]. Long term vitamin $D$ deficiency (hypovitaminosis D) can lead to over-activation of RAS.

\section{MEDICATION AND VACCINE OF SARS-COV-2}

Currently, there is no medication for CoViD-19 approved by FDA, antiviral therapies such as ritonavir and lopinavir, with or without ribavirin have shown some success in the treatment of SARS [34], meanwhile, trials phase III of remdesivir, ritonavir and lopinavir had been initiated [35], although, the use of corticosteroids is controversial [36]. Some studies report that nausea, vomiting, and diarrhea were uncommon symptoms of the CoViD-19 patients [37], but other studies were contrary to this study [28] were diarrhea and nausea were more common [38].

\section{IGM AND/OR IGG ANTIBODY TEST FOR SARS-COV-2 DIAGNOSIS}

$\lg M$ and/or $\lg G$ detection methods play an important role. the results of IgM and/or IGG will help to know if this COVID-19 pandemic can produce the antibodies and studies will show when and how these antibodies are produced to be used in scientific researches targeting medicine and vaccine of CoViD-19.These methods expand the number of biological samples to use, here, the blood takes place to appreciate the body immunity reaction after a viral infection, we can say a rapid and simple point of care lateral flow immunoassay that can detect IgM and IgG simultaneously against SARS-COV-2 virus in human blood within 15 minutes and detect patients at different infection stages. This SARS-COV-2 IGG/IGM test takes short time about few minutes to have resulted, 20 $\mu \mathrm{l}$ of whole blood sample (or $10 \mu \mathrm{l}$ of serum/plasma sample) is pipette into the sample port followed by adding two to 3 drops (70-100 $\mu \mathrm{L}$ ) of dilution buffer (10 mM PBS Buffer) to drive capillary action along the strip. a positive result of anti-SARS-COV-2 IgM/lgG or the titer of antiSARS-COV-2 IgG antibody in the recovery period was four times or higher than in the acute period [39], This new rapid SARS-COV-2 IgG/lgM combined antibody test kit has several advantages compared to RT-PCR, it saves times and it doesn't require types of equipment, it is simple to perform and only requires minimal training. It can be performed at the bedside, in any clinic or laboratory, at the airport or railways stations [39], another potential application of this test is screening asymptomatic carriers that could spread SARS-COV-2 Virus. The samples don't affect $\lg G$ and $\lg M$ detection with this rapid test. Certainly, this test cannot confirm virus presence, only provide evidence of recent infection, but it provides important immunological evidence for physicians to make the correct diagnosis along with other tests and to start treatments of patients. The current diagnosis 
standard combines clinical symptoms and molecular method, and so many of the symptoms resemble those of common cold and influenza, accurate molecular results is critical for final diagnosis, in combination to the different patient samples containing the variable number of virus, a high proportion of patients were diagnosed as false negatives[40].

\section{MOLECULAR DIAGNOSTIC METHOD TO DETECT SARS-COV-2}

\subsection{Real-Time Reverse Transcription PCR (RT-PCR) To Diagnose the CoVid-19}

Facing the emergence of severe acute respiratory syndrome corona virus 2 (SARSCOV-2), various molecular diagnostic tests are demanded in the laboratories worldwide, Molecular assays for detection of CoViD-19 mostly employing real-time polymerase chain (RT-PCR), PCR produces numerous copies (amplification) of gene or series of genetic sequences by using a primer sequence and DNA Polymerase enzymes to exponentially increase the amount of DNA required for research issues or for laboratory analysis of diagnosis, this method is mainly targeting various combinations of the open reading frame (ORF), envelope (E), nucleocapsid (N) and RNA Polymerase (RdRp) gene [40.41.42], The studies reported more than 100 full-length or partial genomic sequences for SARS-COV-2 strains available on the National Center for Biotechnology Information and GISAID database[1], the diagnostics industries has responded rapidly to develop the rapid nucleic acid detection kit (Table.1) based on these sequences, however, significant differences in the sensitivity and specificity among the kits have been found from clinical application of the developed kits, Wang C. et al established a reference sequence of SARSCOV-2 to facilitate The proper design of polymerase chain reaction (PCR) primers and probes to minimize false negative results and to help the immunological studies on and viral vaccine development [1]. From the different developed kits and reported in studies, The $E$ gene PCR seems to be sufficient for diagnosing a SARS-COV-2 infection but confirmation of a positive result with $\mathrm{RdRp}$ protocol was recommended [1.43] RT-PCR SARS-COV-2 can be performed using nasopharyngeal swabs or another upper respiratory tract specimen, including throat, swab or, more recently saliva. In this method, a variety of RNA gene targets are used by different manufacturers, with most tests targeting 1 or more of the envelope (Env), nucleocapsid (N), spike (S), RNA -dependent RNA polymerase (RdRp), and ORF1 genes. The studies reported that in most patients with symptomatic CoViD-19 infection, viral RNA in the nasopharyngeal swabs as measured by the cycle threshold $(\mathrm{Ct})$ becomes detectable as early as first day of symptoms and peaks within the first week of symptom onset. This positivity starts to decline by week 3 and subsequently becomes undetectable (Fig.1) there, it is very important to note that, the cycle threshold $(\mathrm{Ct})$ values change with the cases of severe infection [44].

Patients with no clinical symptoms remain difficult to detect this virus by RT-PCR and unfortunately continue to spread this pandemic through a family contact, with some studies reporting that death of patients with CoViD-19 occurs 28 days after viral exposure in nonsurvivors and that the meantime from admission to the Intensive Care Unit (ICU) to death was 7 days for non-survivors [45], The selection of biological samples to detect viral RNA is still an essential stage; this step will help to target the high viral load to ensure that the sensitivity of the kits used can provide reliable and meaningful results, thus avoiding false findings that can put the therapy and the risk to patients at risk. Serological diagnosis is also becoming an important tool for understanding the spread of COVID-19 in the community and for identifying people who are immunized and potentially protected against infection.

It is especially important for patients with mild-tomoderate disease that may develop late, beyond the first two weeks of disease onset. Total antibody levels begin to rise from the second week of symptom onset [2], findings show that antibodies are positive as early as the fourth day after the onset of symptoms, with higher levels appearing during the second and third weeks of disease, IGG antibodies remain after 7 weeks but $\lg \mathrm{M}$ antibodies begin to decline and reach lowest levels at week 5 and almost completely disappear at week 7 [46], the combination of RTPCR and ELISA diagnostic methods allows the monitoring of the SARS-COV-2 infection and its evolution to develop specific therapy. 


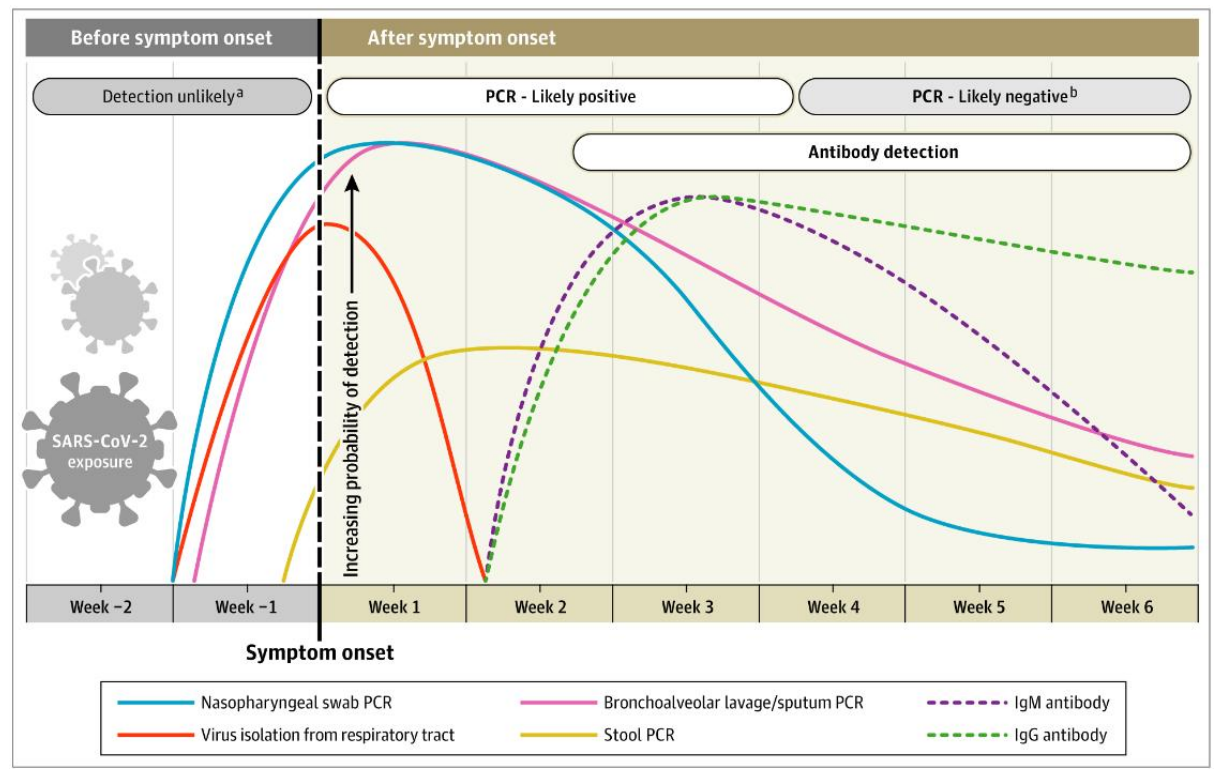

Fig. 1. Estimated time intervals and rates of viral detection are based on data from several published reports. Because of variability in values among studies, estimated time intervals should be considered approximations and the probability of detection of SARS-COV-2 [44]

\subsection{Reverse Transcription Loop- Mediated Isothermal Amplifi-Cation (RTLAMP) to Diagnose the Covid-19}

Some researchers show the development and evaluation of RT-LAMP assays to detect genomic RNA of SARS-COV-2 (Table.2). RTLAMP is one-step nucleic acid amplification method that is used in the diagnosis of infectious diseases caused by bacteria or virus Loopmediated isothermal amplification (LAMP) is a technology that provides nucleic acid amplification in a short time using 4 to 6 specially designed primers and a DNA polymerase with chain displacement activity (Bst) under constant temperature $\left(60-65^{\circ} \mathrm{C}\right), \mathrm{RT}$-LAMP is a rapid and reliable method to amplify from a small amount target sequence at a single reaction temperature, obviating the need of sophisticated thermal cycling equipment [50.51]. After much research about LAMP methods, LAMP is now a standard method for simple isothermal diagnostics. Visual detection of LAMP amplification using Phsensitive dyes seems to be more convenient and secure [52].LAMP can be combined with reverse transcriptase RT-LAMP), were both reverse transcription and amplification occur simultaneously allowing the direct detection of RNA, this system, can be coupled with a $\mathrm{PH}$ indicator present in the reaction mix allowing readout of the amplification reaction by the change in color [52].RT-LAMP has realized successfully on SARS-COV-2 its sensitivity and reaction time was very simple to permit to detect many cases in few times, like this, the infected person will be known early and treatment begins very soon to save the lives. The bibliography reports the research about RT-LAMP CoViD-19 and the proof about the specificity of this method without cross-reactivity to another human coronavirus. The reaction can be performed and interpreted with a very simple instrument such as drying oven or water bath [53], the performance of assay may be further modified by adopting other detection methods and using other enzyme systems. The ability to detect an infectious agent in a widespread is crucial to the success of quarantine efforts in addition to the sensitive and accurate screening of potential cases of infection from patients in a clinical setting. Permitting to be able to test outside of well-equipped laboratories expands the scope of control and surveillance efforts, but also requires robust and simple methods that can be used without expensive instrumentation. This method can be used from purified RNA or cell lysis using a visual, colorimetric detection [22]. It is thus urgent to develop rapid, accurate, and on-site diagnosis methods to effectively identify these early infects, treat them on time, and control the disease spreading. Colorimetric detection is very used in RT-LAMP with a successful agreement with real-time Detection across a range of $\mathrm{Cq}$ value. 
Table 1. Reported studies with Reverse transcription real-time polymerase chain reaction about SARS-COV-2, the pathogen agent of CoViD-19

\begin{tabular}{|c|c|c|c|c|}
\hline Studies & Samples used & Gene target & $\begin{array}{l}\text { Most common } \\
\text { symptoms }\end{array}$ & SARS-COV-2 Interpretation \\
\hline (Wang, et al., 2020) [20] & $\begin{array}{l}\text { Pharyngeal } \\
\text { swabs,blood,sputum,feces, urine, nasal } \\
\text { samples }\end{array}$ & Orf1ab RT-PCR & $\begin{array}{l}\text { Fever, dry } \\
\text { cough, fatigue }\end{array}$ & $\begin{array}{l}\text { Bronchoalveolar lavage is the highest } \\
\text { positive rates, none of the urine } \\
\text { specimens tested positive and nasal } \\
\text { swabs indicate high viral loads }\end{array}$ \\
\hline (Yang Pan et al,, 2020) [47] & Throat swabs,sputum,urine,stool & $\begin{array}{l}\text { N gene Specific RT- } \\
\text { PCR }\end{array}$ & Not specified & $\begin{array}{l}\text { Sputum samples showed higher viral } \\
\text { loads than swab samples, no viral RNA } \\
\text { was detected in urine or stool samples }\end{array}$ \\
\hline $\begin{array}{l}\text { (Yongjian Wu, et al,2020) } \\
{[48]}\end{array}$ & Respiratory and faecal samples & RdRp and E gene & $\begin{array}{l}\text { Gastrointestinal } \\
\text { symptoms }\end{array}$ & $\begin{array}{l}\text { The presence of Gastrointestinal } \\
\text { symptoms was not associated with } \\
\text { faecal sample viral RNA positivity, } \\
\text { antiviral treatment was positively } \\
\text { associated with the presence of viral } \\
\text { RNA in faecal samples, }\end{array}$ \\
\hline (Fei Xiao et al, 2020) [49] & $\begin{array}{l}\text { Faeces, serum, nasopharyngeal } \\
\text { swabs,oropharyngeal } \\
\text { swabs, urine,stool and tissues }\end{array}$ & $\begin{array}{l}\text { RT-PCR and } \\
\text { immunofluorescence } \\
\text { staining }\end{array}$ & $\begin{array}{l}\text { Cough and } \\
\text { fever }\end{array}$ & $\begin{array}{l}\text { Some patients continued to have } \\
\text { positive results in stool after showing } \\
\text { negative results in respiratory samples }\end{array}$ \\
\hline $\begin{array}{l}\text { (Jasper Fuk-W et al 2020) } \\
\text { [63] }\end{array}$ & $\begin{array}{l}\text { nasopharyngeal aspirate / swab, } \\
\text { throat swab, and/or sputum } \\
\text { specimens and non-respiratory tract } \\
\text { specimens (plasma-urine-rectal } \\
\text { swabs and faeces) }\end{array}$ & $\begin{array}{l}\text { RdRp/Hel, RdRp- } \\
\text { P2,S, and N genes }\end{array}$ & Not specified & $\begin{array}{l}\text { COVID-19-RdRp/Hel assay was highly } \\
\text { sensitive and specific for the detection } \\
\text { of SARS-CoV-2 than CoViD-19-RdRp- } \\
\text { P2, besides, this CoViD-19-RdRp-P2 } \\
\text { cross-reacted with SARS-COV. }\end{array}$ \\
\hline
\end{tabular}


Table 2. Studies made with Reverse transcription loop-mediated isothermal amplification (RT-LAMP) about SARS-COV-2, the pathogen agent of CoViD-19

\begin{tabular}{|c|c|c|c|c|}
\hline Studies & Used samples & Target gene & Primers & SARS-COV-2 results comments \\
\hline 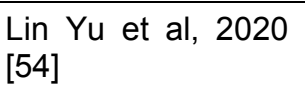 & Respiratory samples & ORF1ab gene & Not specified & $\begin{array}{l}\text { Sensitivity of } 10 \text { copies of orf1ab } \\
\text { gene }\end{array}$ \\
\hline $\begin{array}{l}\text { (Weihua Yang et } \\
\text { al, 2020) [55] }\end{array}$ & throat swab specimens & $\begin{array}{l}\text { ORF1ab gene, } \mathrm{E} \text { gene and } \mathrm{N} \\
\text { gene in same time }\end{array}$ & $\begin{array}{l}\text { (GenBank } \\
\text { No.MN988669.1) }\end{array}$ & $\begin{array}{l}\text { ORF1ab gene was very specific } \\
\text { and } \mathrm{N} \text { gene was very sensitivity }\end{array}$ \\
\hline $\begin{array}{l}\text { (Park G-S, et al } \\
2020)[56]\end{array}$ & $\begin{array}{l}\text { Clinicals } \\
\text { samples }\end{array}$ & $\begin{array}{l}\text { Nsp3 gene, Spike (S), Orf8 gene } \\
\text { and Nucleocapsid (N) gene }\end{array}$ & $\begin{array}{l}\text { Five SARS-CoV-2 sequences } \\
\text { (MN908947, MN938384, } \\
\text { MN988713, MN985325, and } \\
\text { MN975262) and }\end{array}$ & $\begin{array}{l}\text { Two primer sets, both targeting } \\
\text { Nsp3, showed best sensitivity that } \\
\text { showed specific amplification at } 10^{-6} \\
\text { RNA }\end{array}$ \\
\hline $\begin{array}{l}\text { (Renfei Lu \& Jianru } \\
\text { Qin, 2020) [57] }\end{array}$ & $\begin{array}{l}\text { Clinicals } \\
\text { samples }\end{array}$ & $\begin{array}{l}\mathrm{N} \text { gene, } \mathrm{S} \text { gene and } \mathrm{RdRp} \\
\text { gene }\end{array}$ & $\begin{array}{l}\text { (GenBank access number } \\
\text { MN908947.3) }\end{array}$ & $\begin{array}{l}\text { RdRp primers showed higher } \\
\text { amplification efficiency than other } \\
\text { primers and sensitivity of } 3 \text { copies } \\
\text { of SARS-COV-2 RNA per } 25 \mu \mathrm{L}\end{array}$ \\
\hline $\begin{array}{l}\text { (Yun Hee B. et al, } \\
2020 \text { ) [58] }\end{array}$ & Nasals swabs & Nucleocapsid $(\mathrm{N})$ gene & $\begin{array}{l}\text { (GenBank Accession } \\
\text { NC_045512) }\end{array}$ & $\begin{array}{l}\text { The RTLAMP assay was able to } \\
\text { detect down to } 10^{2} \text { copies of SARS- } \\
\text { COV-2 RNA per reaction, } \\
\text { sensitivity of } 100 \% \text { and a specificity } \\
\text { of } 98.70 \%\end{array}$ \\
\hline $\begin{array}{l}\text { (Wei E. Huang } \\
\text { Boon Lim, 2020) } \\
{[59]}\end{array}$ & $\begin{array}{l}\text { Clinicals } \\
\text { samples }\end{array}$ & $\begin{array}{l}\text { orf1ab, } \mathrm{S} \text { gene and } \mathrm{N} \text { gene. } \mathrm{A} \\
\text { colorimetric change was } \\
\text { the region of orf1ab, } \mathrm{S} \text { gene and } \\
\mathrm{N} \text { gene }\end{array}$ & $\begin{array}{l}\text { orf1ab, } S \text { gene and } N \text { gene. } A \\
\text { colorimetric change was } \\
\text { multiplex to amplify specifically } \\
\text { the region of orf1ab, } S \text { gene } \\
\text { and } N \text { gene }\end{array}$ & $\begin{array}{l}\text { The detection limit is } 80 \text { copies of } \\
\text { viral RNA per sample. The study } \\
\text { reported the multiplex SARS-COV-2 } \\
\text { RT-LAMP of } 3 \text { genes }\end{array}$ \\
\hline
\end{tabular}

The RT-LAMP stays an alternative molecular diagnostic method to detect the SARS-COV-2 rapidly without sophist
reported and it is validated by World Health organization 
Table 3. Comparison of reverse transcription real-time polymerase chain reaction (RT-PCR) and reverse transcription loop-mediated isothermal amplification in diagnostic of SARS-COV-2 (RT-LAMP), the pathogen agent of CoViD-19 [60]

\begin{tabular}{|c|c|c|}
\hline Factors & RT-PCR & RT-LAMP \\
\hline Reaction time & At least 2 hours & $15-45$ minutes \\
\hline Protocols & Multiple protocols & Single protocol \\
\hline sensitivity & Sensitive & Sensitive \\
\hline Rapidity & Always requires sample concentration and preparation (time-consuming) & Sample preparation steps are very simplified \\
\hline Primers & Two primers (forward and Reverse) & 4 to 6 primers (F3-B3-FIP-BIP-LF and LB) \\
\hline \multirow[t]{5}{*}{ Temperature conditions } & Thermocycler required & One step Isothermal $63^{\circ} \mathrm{C}$ \\
\hline & Reverse transcription $50^{\circ} \mathrm{C}$ for 5 minutes & \\
\hline & Initial denaturation $94^{\circ} \mathrm{C}$ for 2 minutes & \\
\hline & 40 cycles of denaturation $94^{\circ} \mathrm{C}$ for 5 seconds & \\
\hline & Annealing $55^{\circ} \mathrm{C}$ for 10 seconds & \\
\hline Limitations & Need high purity samples and expensive laboratory instruments & Difficult to detect the multiplex sequences \\
\hline Detection methods & gel electrophoresis & 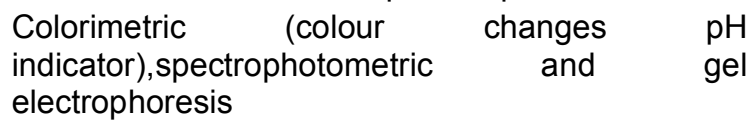 \\
\hline Inhibition & Inhibitors hinder the reaction & Tolerate inhibitors and more stable. \\
\hline Reaction incubation & Thermocycler & Heat block or water bath \\
\hline Use & Standard method in diagnostic and scientific research & $\begin{array}{l}\text { Alternative method in diagnostic and scientific } \\
\text { research }\end{array}$ \\
\hline
\end{tabular}




\section{CONCLUSION}

A pandemic of respiratory diseases caused by severe acute respiratory syndrome coronavirus 2 (SARS-COV-2) is a public health issue, the numbers of infected cases keep increasing, today, To control the current pandemic, some measures were taken like early identification of potentials patients and diagnosis followed by isolation, give the promising results, because of the asymptomatic positive cases who spread the contamination, the suggestion of World health organization (WHO) of mass-screening help to understand real epidemiological details and facilitate the pandemic management, the drugs and vaccines are tested but we don't know when will be the validation, It is the work of everyone where take decisions together may be engaged, every research centre, scientific industries, and the publications editors must share publicly the knowledge about this pandemic to facilitate the research hypothesis about drugs and vaccine. This will help the scientists to compare the research skills to make all people informed about what happened. It is very important to develop diagnostic methods that cover all kinds of biological samples, sensitive and specific, rapids, simples, easy to use, and without additional required equipment, this will be great potential benefits for the fast screening of SARS-COV-2 Infection. The coronaviruses are sensitive to the heat exposure $56^{\circ} \mathrm{C}$ for 30 minutes as well as solvents including $75 \%$ ethanol, chlorinecontaining disinfectant, peroxyacetic acid, and chloroform [61], this information stays important in sanitary measures to stop the virus by washing hands frequently using soap or hydro-alcoholic solution World health organization(WHO) recommend to everyone the generals measures like to Wash the hands regularly with soap and water, or to clean with alcohol-based hand liquid or other sanitizing, to Maintain at least 1 metre distance between the people, to Avoid touching the face, to remember covering the mouth and nose when coughing or sneezing, to do not smoke and other activities that weaken the lungs organs, the physical distancing by avoiding unnecessary travel and staying away from large groups of people and to take in quarantine of isolation of an infected person.

Some research papers report the false negatives results; we have to know that SARS-COV-2 infection starts at the lung, not in the upper respiratory tract [62]; therefore sampling during the early infection stage using throat swab of sputum may not detect the virus. This is one possible explanation for high false negatives in the nucleic acid PCR test reported, Colorimetric LAMP provides a simple, rapid method for SARS-COV-2 RNA detection, not only purified RNA can be used as the sample input, but also direct tissue or cell lysate may be used without an RNA purification step. This combination of quick sample preparation method with an easy detection process may allow the development of portable, field detection in addition to rapid screening for point-of-need testing applications. By using a real-time RT-LAMP assay, the quantification of virus concentration in the clinical sample is possible, and, will indicate the early stage of the virus infection as well as potential source transmitters. Today, the findings report that the worldwide measurements keep on showing promising results and COVID-19 is weakening but, As the virus has not yet revealed all its secrets of survival, transmission, and unavailability of medicine or vaccine, it is highly recommended to fund the WHO (world health organization), medical research centers and laboratories to respond to this great challenge that has impacted all sectors of public health, the economy, social and psychological life.

\section{COMPETING INTERESTS}

Authors have declared that no competing interests exist.

\section{REFERENCES}

1. Huang C, Wang $Y$, Li X, Ren L, Zhao J, Cheng Z, et al. Clinical features of patients infected with 2019 novel coronavirus in Wuhan, China. The lancet.2020;395(10223)4:97-506.

2. Lu R, Zhao X, Li J, Niu P, Yang B,Bi Y, et al. Genomic characterisation and epidemiology of 2019 novel coronavirus: Implications for virus origins and receptor binding. The Lancet, 2020;395(10224):565-574.

3. Zhu N, Zhang D, Wang W, Li X, Yang B, Niu $P$, et al. A novel coronavirus from patients with pneumonia in China, 2019. New England Journal of Medicine.2020;382:727-733

4. Wu F, Zhao S, Yu B, Chen YM, Wang W, Yuan $\mathrm{ML}$, et al. A new coronavirus associated with human respiratory disease in China. Nature. 2020;579(7798):265-269.

5. Marra MA, Jones SJ, Astell CR, Holt RA, Brooks-Wilson $A, C l o u t i e r ~ A$, et al. The genome sequence of the SARS-associated 
coronavirus. Science. 2003;300(5624):139 9-1404.

6. Zheng J. SARS-CoV-2: an emerging coronavirus that causes a global threat. International journal of biological sciences. 2020;16(10):1678.

7. Lam TTY, Jia N, Zhang YW, Shum MHH, Jiang JF, Li WJ, et al. Identifying SARSCoV-2-related coronaviruses in Malayan pangolins. Nature. 2020;1-4.

8. Al-Muharraqi MA. Testing recommendation for COVID-19 (SARS-CoV-2) in patients planned for surgery-continuing the service and 'suppressing 'the pandemic.The British Journal of Oral \& Maxillofacial Surgery, 2020;58(5):503505.

9. Amirian ES. Potential fecal transmission of SARS-CoV-2: current evidence and implications for public health. International Journal of Infectious Diseases. 2020;363370.

10. Zhang $\mathrm{H}$, Kang Z, Gong H, Xu D, Wang J, Liu $\mathrm{J}$, et al. The digestive system is a potential route of 2019-nCov infection: a bioinformatics analysis based on singlecell transcriptomes. Bio Rxiv; 2020.

DOI: https://doi.org/10.1101/2020.01.30.92 7806.

11. Su S, Wong G, Shi W, Liu J, Lai AC, Gao GF, et al, Epidemiology, genetic recombination, and pathogenesis of coronaviruses. Trends Microbiology. 2016;24(6):490-502.

12. Chan JF, Lau SK, To KK, Cheng VC, Woo PC, Yuen KY. Middle east respiratory syndrome coronavirus: Another zoonotic betacoronavirus causing SARS-like disease. Clinical Microbiology Reviews. 2015;28(2):465-522.

13. Drosten C, Günther S, Preiser W, Van Der Werf $S$, Brodt HR, Berger A, et al. Identification of a novel coronavirus in patients with severe acute respiratory syndrome. New England Journal of Medicine. 2003;348(20):1967-1976.

14. Zaki AM, Van Boheemen $S$, Bestebroer TM, Osterhaus AD, Fouchier RA. Isolation of a novel coronavirus from a man with pneumonia in Saudi Arabia. New England Journal of Medicine, 2012;367(19):1814-1820.

15. Xiao K, Zhai J, Feng Y, Zhou N, Zhang X, Zhang $Z$, et al. Isolation and characterization of 2019-nCoV-like coronavirus from Malayan pangolins. BioRxiv;2020.
16. DOI: https://doi.org/10.1101/2020.02.17.95 1335

17. Wang $\mathrm{H}$, Li X, Li T, Zhang S, Wang L, Liu $\mathrm{J}$, et al.The genetic sequence, origin, and diagnosis of SARS-CoV-2. European Journal of Clinical Microbiology \& Infectious Diseases. 2020,1-7

18. Heald-Sargent T, Gallagher ReadyT.Set, fuse! The coronavirus spike protein and acquisition of fusion competence. Viruses. 2012;4(4):557-580.

19. Gallagher TM, Buchmeier MJ.Coronavirus spike proteins in viral entry and pathogenesis. Virology. 2001;279(2):371374.

20. Zou L, Ruan F, Huang M, Liang L, Huang $\mathrm{H}$, Guo $\mathrm{Q}$ et al. SARS-CoV-2 viral load in upper respiratory specimens of infected patients. New England Journal of Medicine. 2020;382(12):1177-1179.

21. Wang W, Xu Y, Gao R, Lu R, Han K, Tan $W$, et al. Detection of SARS-CoV-2 in different types of clinical specimens. Jama. 2020;323(18):18431844.

22. Chan JFW, Yuan S, Kok KH, To KKW, ChuTsoi HW et al. A familial cluster of pneumonia associated with the 2019 novel coronavirus indicating person-to-person transmission: a study of a family cluster. The Lancet. 2020;395(10223):514523.

23. Zhang $\mathrm{Y}$, Odiwuor N, Xiong J, Sun L, Nyaruaba RO, Tanner NA, et al. Rapid molecular detection of SARS-CoV-2 (COVID-19) virus RNA using colorimetric LAMP. MedRxiv; 2020,DOI: https://doi.org/10.1101/2020.02. 26.20028373

24. Tian, H. Y. 2019-nCoV: New challenges from coronavirus. Zhonghua yu fang yi xue za zhi[Chinese journal of preventive medicine]. 2020;54:E001-E001.

25. Wölfel R, Corman VM, Guggemos W, Seilmaier M, Zange S, Hoelscher M.et al. Virological assessment of hospitalized patients with COVID2019. Nature. 2020;581(7809):465-469.

26. Ng K, Poon BH, Kiat Puar TH, Shan Quah JL, Loh WJ, Raghuram J. COVID-19 and the risk to health care workers: A case report. Annals of Internal Medicine. 2020;766-767.

27. Lou B, Li T, Zheng S. Serology characteristics of SARS-CoV-2 infection since the exposure and post symptoms onset. MedRxiv; 2020. 
28. Azzi L, Carcano G, Gianfagna F, Grossi P, Dalla Gasperina D, Maurino V. et al. Saliva is a reliable tool to detect SARS-CoV2. Journal of Infection.2020;2020:e45-e50

29. Lo IL, Lio CF, Cheong $\mathrm{HH}$, Lei $\mathrm{Cl}$, Cheong $\mathrm{TH}$, Sin NN, et al. Evaluation of SARSCoV-2 RNA shedding in clinical specimens and clinical characteristics of 10 patients with COVID-19 in Macau. International Journal of Biological Sciences. 2020;16(10)1:698.

30. Perlot T, Penninger JM. ACE2-From the renin-angiotensin system to gut microbiota and malnutrition. Microbes and infection. 2013;15(13):866-873.

31. Cao Z, Wu Y, Faucon E, Sabatier JM. SARS-CoV-2 \& Covid-19: Key-roles of the'renin-angiotensin'system/Vitamin impacting drug and vaccine developments. Infectious Disorders Drug Targets;2020.

DOI: 10.2174/1871526520999200505174704.

32. Cynthia, A. Vitamin-D and the Immune System. Journal of Investigative Medicine. 2011;59:881-886.

33. Leung PS. The modulatory action of Vitamin $D$ on the renin-angiotensin system and the determination of hepatic insulin resistance. Molecules.2019;24(13):2479.

34. Ajabshir S, Asif A, Nayer A. The effects of vitamin $D$ on the renin-angiotensin system. Journal of Nephropathology. 2014;3(2);41-43.

35. Zhang L, Liu Y. Potential interventions for novel coronavirus in China: A systematic review. Journal of Medical Virology.2020;92(5):479-490.

36. Li Guangdi, Erik De Clercq. Therapeutic options for the 2019 novel coronavirus (2019-nCoV).2020;149-150.

37. Shang L, Zhao J, Hu Y, Du R, Cao B. On the use of corticosteroids for 2019-nCoV pneumonia. Lancet England). 2020;395(10225):683.

(London,

38. Guan WJ, Ni ZY, Hu Y, Liang WH, Ou CQ, $\mathrm{Du}$ B. et al. Clinical characteristics of coronavirus disease 2019 in China. New England journal of medicine. 2020;382(18):1708-1720.

39. Zhang W, Zhao Y, Zhang F, Wang Q, Li T, Zeng $X$, et al. The use of anti-inflammatory drugs in the treatment of people with severe coronavirus disease 2019 (COVID19): The experience of clinical immunologists from China. Clinical Immunology, 2020;108393.
40. Li Z, Yi Y, Luo X, Xiong N, Liu Y, Zhang Y, et al. Development and clinical application of a rapid IgM-lgG combined antibody test for SARS-CoV-2 infection diagnosis. Journal of medical virology.2020;1-7.

41. Huang C, Wang $\mathrm{Y}$, Li X, Ren L, Zhao J,Cheng $Z$, et al. Clinical features of patients infected with 2019 novel coronavirus in Wuhan, China. The lancet. 2020;395(10223):497-506.

42. Chu DK, Pan Y, Cheng SM, Hui KP, Krishnan $P$, Peiris $M$, et al. Molecular diagnosis of a novel coronavirus (2019$\mathrm{nCoV}$ ) causing an outbreak of pneumonia. Clinical

Chemistry. 2020;66(4):549-555.

43. Kashir J, Yaqinuddin A. Loop mediated isothermal amplification (LAMP) assays as a rapid diagnostic for COVID-19. Medical Hypotheses.2020;109786:1-5

44. Corman VM Landt $O$, Kaiser $M$, Molenkamp R, Meijer A, Mulders DG, et al. Detection of 2019 novel coronavirus (2019$\mathrm{nCoV}$ ) by real-time RTPCR. Eurosurveillance.

2020;25(3):2000045.

45. Sethuraman $N$, Jeremiah SS, Ryo $A$. Interpreting diagnostic tests for SARSCoV-2. Jama.2020;323(22):2249-2251.

46. Yang $X, Y u Y, X u$ J, Shu $H$, Liu H, Wang $Y$, et al. Clinical course and outcomes of critically ill patients with SARS-CoV-2 pneumonia in Wuhan, China: a singlecentered, retrospective, observational study. The Lancet Respiratory Medicine. 20204;75-481.

47. Xiang F, Wang X, He X, Peng Z, Yang B, Wei $X$. Antibody detection and dynamic characteristics in patients with COVID19. Clinical Infectious Diseases;2020., Available:https://doi.org/10.1093/cid/ciaa46 1

48. Pan Y, Zhang D, Yang P, Poon LL, Wang Q. Viral load of SARS-CoV-2 in clinical samples. The Lancet Infectious Diseases. 2020;20(4):411-412.

49. Wu Y, Guo C, Tang L, Hong Z, Zhou J, Kuang $L$, et al. Prolonged presence of SARS-CoV-2 viral RNA in faecal samples. The lancet Gastroenterology \& hepatology. 2020;5(5):434-435.

50. Xiao F, Tang M, Zheng X, Liu Y, Li X, Shan $H$. Evidence for gastrointestinal infection of SARS-CoV2. Gastroenterology. 2020;158(6):18311833. 
51. Notomi T, Okayama $\mathrm{H}$, Masubuchi $\mathrm{H}$, Yonekawa T, Watanabe $\mathrm{K}$, Hase $\mathrm{T}$, et al. Loop-mediated isothermal amplification of DNA. Nucleic

acids research. 2000;28(12):e63-e63.

52. Nagamine $\mathrm{K}$, Hase $\mathrm{T}$, Notomi $\mathrm{T}$. Accelerated reaction by loop-mediated isothermal amplification using loop primers. Molecular and cellular probes. 2002;16(3):223-230.

53. Tanner NA, Zhang Y, Evans Jr TC. Visual detection of isothermal nucleic acid amplification using $\mathrm{pH}$-sensitive dyes. Biotechniques. 2015;58(2):59-68.

54. Uwiringiyeyezu T, El Khalfi B, Belhachmi J, Soukri A. Loop-mediated Isothermal Amplification LAMP, Simple Alternative Technique of Molecular Diagnosis Process in Medicals Analysis: A Review. Annual Research \& Review in Biology. 2019;1-12.

55. Yu L, Wu S, Hao X, Li X, Liu X, Liu J, et al. Rapid colorimetric detection of COVID-19 coronavirus using a reverse tran-scriptional loop-mediated isothermal amplification (RT-LAMP) diagnostic plat-form: iLACO. MedRxiv; 2020.

DOI:10.1101/2020.02.20.20025874

56. Yang W, Dang X, Wang Q, Xu M, Zhao Q, Han S. et al. Rapid detection of SARSCoV-2 using reverse transcription RTLAMP method. MedRxiv; 2020. DOI:10.1101/2020.03.02.20030130

57. Park GS, Ku K, Baek SH, Kim SJ, Kim SI, Maeng JS, et al. Development of reverse transcription loop-mediated isothermal amplification (RT-LAMP) assays targeting SARS-CoV-2. The Journal of Molecular Diagnostics.2020;729-735.

58. Lu R, Wu X, Wan Z, Li Y, Zuo L, Zhang, et al. Development of a novel reverse transcription loop-mediated isothermal amplification method for rapid detection of SARS-CoV-2. Virologica Sinica. 2020, 1-4.

59. Baek YH, Um J, Antigua KJC, Park $\mathrm{JH}$, Chin BS, et al. Development of a reverse transcription-loop-mediated isothermal amplification as a rapid earlydetection method for novel SARS-CoV2. Emerging Microbes \&Infections. 2020;9(1):998-1007.

60. Huang WE, Lim B, Hsu CC, Xiong D, Wu W, Chang $\mathrm{H}$, et al. RT-LAMP for rapid diagnosis of coronavirus SARS-CoV-2. Microbial biotechnology. 2020;13(4):950-961.

61. Nguyen T, Duong Bang D, Wolff A. 2019 novel coronavirus disease (COVID-19): paving the road for rapid detection and point-of-care diagnostics. Microachines. 2020;11(3):306.

62. Commission $\mathrm{NH}$. Diagnosis and treatment protocol for novel coronavirus pneumonia. Chinical Medicine Journal. 2020;10871095.

63. Tian S, Hu W, Niu L, Liu $H, X u ~ H$, Xiao SY. Pulmonary pathology of early phase SARS-COV-2 pneumonia; 2020. DOI: $10.20944 /$ preprints202002.0220

(c) 2020 Uwiringiyeyezu et al.; This is an Open Access article distributed under the terms of the Creative Commons Attribution License (http://creativecommons.org/licenses/by/4.0), which permits unrestricted use, distribution, and reproduction in any medium, provided the original work is properly cited.

Peer-review history:

The peer review history for this paper can be accessed here: http://www.sdiarticle4.com/review-history/59098 